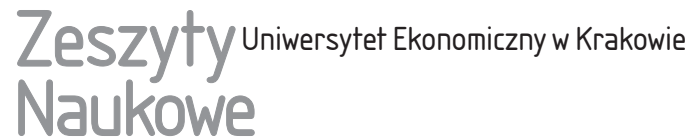

\section{Definicje i klasyfikacje kategorii ekonomicznych w badaniach nad współczesnymi zjawiskami finansowymi}

\section{Streszczenie}

Badania nad współczesnymi zjawiskami finansowymi wymagają posługiwania się informacjami o kategoriach ekonomicznych, z których znaczną część stanowią kategorie ekonomiczne ujawniane w sprawozdaniach finansowych. Warunkiem zapewnienia wysokiej jakości prowadzonych badań jest spójność definicji i klasyfikacji kategorii ekonomicznych.

Głównym celem artykułu jest zwrócenie uwagi środowiska teoretyków finansów, prawa i rachunkowości na potrzebę wzmożenia prac badawczych ukierunkowanych na doskonalenie oraz tworzenie nowych definicji i klasyfikacji kategorii ekonomicznych ujawnianych w sprawozdaniach finansowych podmiotów sprawozdawczych.

Dla uzasadnienia powyższej tezy w artykule przedstawiono analizę aktualnego stanu w tym zakresie w sprawozdaniach finansowych sporządzanych według MSSF i polskiego prawa o rachunkowości na przykładzie informacji o przychodach i kosztach finansowych, a także posługiwania się pojęciem działalności finansowej na płaszczyźnie normatywnej i edukacyjnej oraz w praktyce gospodarczej. Określono również przyczyny i skutki nieporozumień w tym zakresie, co może być pomocne w badaniach ukierunkowanych na ich likwidację, a zatem na doskonalenie tworzenia informacji o zasadniczym znaczeniu dla rozwoju teorii, prawa i praktyki gospodarczej.

Słowa kluczowe: kategorie ekonomiczne, przychody finansowe, koszty finansowe, działalność finansowa.

Klasyfikacja JEL: M41.

Danuta Krzywda, Uniwersytet Ekonomiczny w Krakowie, Wydział Finansów i Prawa, Katedra Rachunkowości Finansowej, ul. Rakowicka 27,31-510 Kraków, e-mail: krzywdad@uek.krakow.pl 


\section{Wprowadzenie}

Badania nad współczesnymi zjawiskami finansowymi wymagają posługiwania się informacjami o kategoriach ekonomicznych, z których znaczną część stanowią informacje ujawniane w sprawozdaniach finansowych. Warunkiem zapewnienia wysokiej jakości prowadzonych badań jest spójność definicji i klasyfikacji kategorii ekonomicznych.

Definiowanie i klasyfikowanie pojęć należy do podstawowych zadań teoretyków i jest przejawem rozwoju teorii w danej dziedzinie naukowej. Kategorie ekonomiczne ujawniane w sprawozdaniach finansowych powinny być zatem przedmiotem prac badawczych w szczególności z zakresu finansów i rachunkowości.

Mając na uwadze obligatoryjny charakter rachunkowości, sprawozdawczości i rewizji finansowej, a tym samym konieczność stosowania w praktyce rachunkowości i rewizji finansowej definicji określonych w normach prawnych rachunkowości, obserwuje się:

- niewystarczające zainteresowanie teoretyków doskonaleniem istniejących definicji i klasyfikacji w stosunku do potrzeb i wymogów praktyki gospodarczej, a także instytucji odpowiedzialnych za stanowienie norm prawnych, oraz wynikający z tej przyczyny nikły wpływ badań naukowych na poszukiwanie nowych - dostosowanych do zmieniających się warunków ekonomicznych i społecznych definicji i klasyfikacji kategorii ekonomicznych,

- przyjmowanie definicji i klasyfikacji normatywnych jako słusznej i niepodważalnej podstawy w ramach prowadzonych badań naukowych,

- stosunkowo częste błędne interpretacje definicji normatywnych, wynikające $\mathrm{z}$ różnych przyczyn, w tym z błędnego tłumaczenia norm międzynarodowych.

Definicje i klasyfikacje kategorii ekonomicznych określone w normach prawnych wykorzystywane są jednak przede wszystkim w praktyce rachunkowości, sprawozdawczości i rewizji finansowej. Poprawność tych definicji i klasyfikacji oraz poprawność ich stosowania w praktyce gospodarczej wpływają zatem nie tylko na jakość badań naukowych prowadzonych na podstawie informacji sprawozdawczych, lecz także na jakość sprawozdawczości i rewizji finansowej, których rezultaty są wykorzystywane do podejmowania decyzji o dostarczaniu kapitału podmiotom sprawozdawczym (jednostkom i grupom kapitałowym), tym samym warunkując możliwość ich funkcjonowania i rozwoju.

W niniejszym artykule podjęto próbę przedstawienia krytycznej analizy wybranych kategorii ekonomicznych, jakimi są m.in. przychody i koszty finansowe, które są ujawniane w rachunku zysków i strat, a następnie są wykorzystywane $\mathrm{w}$ analizie finansowej i w podejmowaniu decyzji zarządczych, jak również w badaniach naukowych. 
Wartości pieniężne osiąganych przychodów finansowych i ponoszonych kosztów finansowych w podmiocie sprawozdawczym w danym okresie kształtują się różnie w zależności od podstawy prawnej sporządzenia sprawozdania finansowego. Inne kwoty będą ujawnione w sprawozdaniu finansowym sporządzonym według polskiej ustawy o rachunkowości niż w sprawozdaniu sporządzonym według międzynarodowych standardów sprawozdawczości finansowej (MSSF).

Zróżnicowanie kwot przychodów i kosztów finansowych występuje również w sprawozdaniach sporządzonych według MSSF i wiąże się z wariantem sprawozdania z wyniku (jednej z dwóch części sprawozdania z wyniku i innych całkowitych dochodów ${ }^{1}$, zwanego dalej sprawozdaniem $\mathrm{z}$ dochodów), jak również specyficznym rozumieniem treści MSSF w Polsce ${ }^{2}$. Informacje o przychodach i kosztach finansowych przedstawione w sprawozdaniach finansowych różnych podmiotów sprawozdawczych na terenie kraju, a tym bardziej w skali międzynarodowej nie są zatem porównywalne i nie stanowią rzetelnej podstawy do analizy i prowadzenia badań, szczególnie o charakterze porównawczym.

Zaprezentowana w niniejszym opracowaniu krytyczna analiza kategorii przychodów i kosztów finansowych może przyczynić się do poprawy jakości informacji sprawozdawczych, a tym samym badań prowadzonych z wykorzystaniem tych kategorii.

\section{Definicje i klasyfikacje kategorii wynikowych w Założeniach koncepcyjnych sprawozdawczości finansowej i w polskiej wersji dokumentu}

Ustawa o rachunkowości (Ustawa z dnia 29 września 1994 r....) definiuje pojęcia przychodów i zysków oraz kosztów i strat. Ustawowe definicje tych pojęć (podobnie jak pojęć aktywów, zobowiązań i kapitału własnego) są oparte na definicjach zawartych pierwotnie w Założeniach koncepcyjnych sporzqdzania i prezentacji sprawozdań finansowych (Założenia koncepcyjne... 2001), aktualnie zaś w Założeniach koncepcyjnych sprawozdawczości finansowej (The Conceptual Framework... 2016) ${ }^{3}$, zwanych dalej założeniami koncepcyjnymi. Jest to doku-

${ }^{1}$ Nazwa tego sprawozdania została zaczerpnięta z wydania książkowego MSSF. Różni się ona od nazwy stosowanej w polskojęzycznej wersji MSR 1 „Prezentacja sprawozdań finansowych”, która brzmi: „sprawozdanie z zysków lub strat i innych całkowitych dochodów” (Rozporządzenie Komisji (WE) nr 1126/2008 z dnia 3 listopada 2008 r....).

${ }^{2}$ Zjawisko specyficznego rozumienia MSSF obserwuje się również w innych krajach.

${ }^{3}$ Założenia koncepcyjne sprawozdawczości finansowej zostały wydane przez IASB we wrześniu 2010 r., zastępując Założenia koncepcyjne sporzqdzania i prezentacji sprawozdań finansowych, które zostały opublikowane w 1989 r. przez IASC - organ będący poprzednikiem IASB. 
ment leżący u podstaw międzynarodowych standardów rachunkowości (MSR), aktualnie określanych mianem międzynarodowych standardów sprawozdawczości finansowej (MSSF).

Założenia koncepcyjne zawierają definicje kategorii ekonomicznych o najwyższym poziomie uogólnienia - kategorii stanowiących składniki sprawozdania finansowego. Składnikami tymi są:

- kategorie bilansowe: aktywa, zobowiązania i kapitał własny - bezpośrednio związane z ustaleniem sytuacji finansowej podmiotu sprawozdawczego (jednostki lub grupy kapitałowej) w sprawozdaniu z sytuacji finansowej na koniec okresu, zwanym dalej bilansem,

- kategorie wynikowe: dochody i koszty - bezpośrednio związane z pomiarem osiągnięć w sprawozdaniu z wyniku i pozostałych całkowitych dochodów za okres (w rachunku zysków i strat rozszerzonego o pozycje pozostałych całkowitych dochodów), zwanym dalej sprawozdaniem z dochodów.

Prezentacja wyżej wymienionych składników w bilansie czy też w sprawozdaniu z dochodów wiąże się z dalszym ich podziałem na podkategorie. Podział powinien być celowy i oparty na wyraźnie określonej podstawie, a subkategorie wynikające z podziału powinny być zdefiniowane.

Założenia koncepcyjne zawierają definicje dochodów i kosztów w następującym oryginalnym brzmieniu (The Conceptual Framework... 2016, s. A38):

"(a) income is increases in economic benefits during the accounting period in the form of inflows or enhancements of assets or decreases of liabilities that result in increases in equity, other than those relating to contributions from equity participants.

(b) expenses are decreases in economic benefits during the accounting period in the form of outflows or depletions of assets or incurrences of liabilities that result in decreases in equity, other than those relating to distributions to equity participants".

W tłumaczeniu na język polski definicje te brzmią następująco (Założenia koncepcyjne... 2016, s. 53):

,(a) dochody to zwiększenia korzyści ekonomicznych w ciągu okresu obrotowego $\mathrm{w}$ formie uzyskania lub zwiększenia aktywów albo zmniejszenia zobowiązań, powodujące przyrost kapitału własnego inny niż przyrost związany z wpłatami udziałowców,

(b) koszty to zmniejszenia korzyści ekonomicznych w trakcie okresu w formie rozchodu lub zmniejszenia aktywów albo powstania zobowiązań, powodujące zmniejszenie kapitału własnego inne niż zmniejszenie związane z podziałem kapitału własnego na rzecz właścicieli” .

Definicje omawianych pojęć sformułowane w języku angielskim są dokładnym swoim przeciwieństwem, co ułatwia zrozumienie ich istoty, zapamiętanie ich 
i stosowanie. W tłumaczeniu na język polski zmieniono sformułowania zawarte w definicjach, co znalazło wyraz w następujących rozbieżnościach pomiędzy anglojęzyczną i polskojęzyczną ich wersją:

- w definicji dochodów użyto określenia „okres obrotowy”, a w definicji kosztów użyto określenia „okres”;

- w definicji dochodów formą zwiększenia korzyści ekonomicznych jest „uzyskanie" aktywów, podczas gdy w definicji kosztów formą zmniejszenia korzyści ekonomicznych jest „rozchód” aktywów; oprócz użycia określeń, które nie są w pełni przeciwstawnymi (choć takie w języku polskim istnieją), wyrażono je w liczbie pojedynczej zamiast - jak w oryginale - w liczbie mnogiej;

- w definicji dochodów mowa jest o przyroście kapitału własnego innym niż przyrost związany z „wpłatami udziałowców”, natomiast w definicji kosztów mowa jest o zmniejszeniu kapitału własnego innym niż zmniejszenie „związane z podziałem kapitału własnego na rzecz właścicieli”.

Odstępstwa od oryginalnego tekstu dokonane w procesie tłumaczenia i redakcji naukowej międzynarodowego dokumentu stanowiącego podstawę koncepcyjną norm międzynarodowych i krajowych nie ułatwiają jego zrozumienia i właściwego wykorzystywania na poziomie krajowym, wręcz przeciwnie - stwarzają dodatkową barierę poznawczą utrudniającą korzystanie z zawartych w nim treści.

Definicje dochodów i kosztów zawarte w założeniach koncepcyjnych określają zasadnicze cechy tych kategorii ekonomicznych, lecz nie określają szczegółowo kryteriów, które muszą zostać spełnione, aby można je było ująć w sprawozdaniu $\mathrm{z}$ dochodów.

Kryteria ujmowania składników sprawozdania finansowego określone są w tym dokumencie odrębnie. Kryteriami ujmowania danej pozycji spełniającej definicję składnika sprawozdania finansowego są (Założenia koncepcyjne... 2016, s. 55):

- prawdopodobieństwo, że jednostka osiągnie jakiekolwiek przyszłe korzyści ekonomiczne związane z tą pozycją lub że nastąpi ich wypływ z jednostki,

- posiadanie przez daną pozycję ceny nabycia lub kosztu wytworzenia lub też wartości, którą można wiarygodnie ustalić.

Powyższe kryteria ujmowania dotyczą kategorii bilansowych, tj. aktywów i zobowiązań, a tym samym kapitału własnego, co wynika z różnicowego charakteru dotychczasowej definicji tego pojęcia. O ile bowiem definicje aktywów i zobowiązań zawarte w założeniach koncepcyjnych objaśniają treść ekonomiczną tych pojęć, o tyle zawarta w nich definicja kapitału własnego: „Kapitał własny to udział w aktywach jednostki pozostały po odjęciu wszystkich jej zobowiązań" (Założenia koncepcyjne... 2016, s. 49) nie objaśnia treści ekonomicznej, a jedynie wskazuje na różnicowy charakter tej kategorii bilansowej.

Wzajemna zależność pomiędzy składnikami sprawozdania finansowego sprawia, że pozycja spełniająca wymogi definicji i kryteria ujmowania danego składnika: 
- dla aktywów - automatycznie wymaga ujęcia innego składnika, tj. dochodów lub zobowiązań, lub kapitału własnego,

- dla zobowiązań i kapitału własnego - automatycznie wymaga ujęcia innego składnika, tj. kosztów lub aktywów.

Jak zauważono wyżej, kryteria ujmowania odnoszą się bezpośrednio do składników sprawozdania finansowego, które są kategoriami bilansowymi, a nie do kategorii wynikowych. Spełnienie przez daną pozycję definicji aktywów lub zobowiązań oraz kryteriów ich ujmowania automatycznie wymaga ujęcia odpowiednio dochodu lub kosztu (chyba że ujęcie tej pozycji bilansowej wywołuje skutek bilansowy, tj. pozycję bilansową o charakterze przeciwnym). Kryteria ujmowania odnoszące się bezpośrednio do kategorii bilansowych odnoszą się zatem pośrednio do kategorii wynikowych. Takie podejście do ujmowania dochodów i kosztów w sprawozdaniu finansowym to podejście bilansowe ${ }^{4}$, zgodnie z którym niedopuszczalne jest:

- ujęcie dochodu, gdy nie nastąpiło pozyskanie lub zwiększenie aktywów, lub zmniejszenie zobowiązań,

- ujęcie kosztu, gdy nie nastąpiło pozbycie się lub zmniejszenie aktywów albo powstanie lub zwiększenie zobowiązań.

Przykładem braku teoretycznej poprawności w tym zakresie jest ujmowanie w bilansie ujemnej wartości firmy. Takie rozwiązanie zawiera ustawa o rachunkowości. Treść ekonomiczna pozycji „ujemna wartość firmy” nie jest zgodna z definicją zobowiązań. Pozycja ta nie jest również kapitałem własnym, ponieważ z wartością (kwotą) ujemnej wartości firmy nie wiąże się żadna wartość (kwota) aktywów. Ujmowanie w bilansie ujemnej wartości firmy zawyża zobowiązania o wartość (kwotę) pozycji, która zobowiązaniem nie jest, a przez to zniekształca obraz źródeł finansowania jednostki. Usprawiedliwieniem opisanej wyżej nieprawidłowości nie może być wskazywanie na zasadę współmierności przychodów i kosztów. Poprawnym rozwiązaniem w tym zakresie jest niezwłoczne ujęcie ujemnej wartości firmy jako dochodu (zysku na okazyjnym nabyciu) ${ }^{5}$. Przestrzeganie zasady współmierności nie może prowadzić do przedstawiania w bilansie nieprawdziwego i nierzetelnego obrazu sytuacji finansowej jednostki.

Dochody to pojęcie złożone. Obejmuje ono przychody i zyski.

Przychody powstają w procesie zwyczajnej działalności jednostki i określane są różnymi nazwami: sprzedaż, opłaty, odsetki, dywidendy, opłaty licencyjne, czynsz.

${ }^{4}$ Podejście bilansowe jest charakterystyczne dla teorii wartości, która jest jednym z dwóch modeli koncepcyjnych dotyczących sposobu realizacji koncepcji prawdziwego i rzetelnego obrazu, w przeciwieństwie do teorii transakcyjnej, w której podstawowe znaczenie ma rachunek zysków i strat.

5 Rozwiązanie takie jest przyjęte w MSSF 3 „Połączenia przedsięwzięć” (Międzynarodowe Standardy Sprawozdawczości Finansowej... 2016). 
Zyskami określa się inne pozycje, które spełniają warunki określone w definicji dochodów oraz mogą, choć nie muszą powstawać w zwyczajnej działalności jednostki. Stanowiąc przyrost korzyści ekonomicznych, w swej istocie nie różnią się od przychodów. Do zysków zalicza się m.in.:

- zyski ze sprzedaży aktywów trwałych,

- niezrealizowane zyski, np. wynikające z aktualizacji wyceny papierów wartościowych znajdujących się w publicznym obrocie czy też wynikające ze wzrostu wartości bilansowej aktywów długoterminowych.

Gdy zyski są ujmowane w sprawozdaniu z dochodów, zazwyczaj przedstawia się je oddzielnie, ponieważ ich znajomość jest użyteczna przy podejmowaniu decyzji gospodarczych. Zyski często przedstawia się w wartości netto, czyli po pomniejszeniu o odnośne koszty.

Koszty - podobnie jak dochody - są pojęciem złożonym. Obejmuje ono koszty i straty.

Koszty powstają w zwyczajnej działalności jednostki i są to np.: koszt własny sprzedaży, wynagrodzenia, amortyzacja. Zazwyczaj przybierają one formę rozchodu lub zmniejszenia wartości aktywów, takich jak środki pieniężne i ich ekwiwalenty, zapasy, rzeczowe aktywa trwałe.

Stratami określa się inne pozycje, które spełniają warunki określone w definicji kosztów oraz mogą, choć nie muszą powstawać w zwyczajnej działalności jednostki. Stanowiąc zmniejszenie korzyści ekonomicznych, w swej istocie nie różnią się od innych kosztów. Do strat zalicza się m.in.:

- straty spowodowane klęskami żywiołowymi,

- straty ze zbycia aktywów trwałych,

- straty niezrealizowane, np. straty powstałe w wyniku wzrostu kursów wymiany waluty obcej w odniesieniu do kredytów zaciągniętych przez jednostkę w tej walucie.

Gdy straty są ujmowane w sprawozdaniu z dochodów, zazwyczaj przedstawia się je oddzielnie, ponieważ ich znajomość jest użyteczna przy podejmowaniu decyzji gospodarczych. Straty często przedstawia się w wartości netto, czyli po pomniejszeniu o odnośne dochody.

W opisanym wyżej podejściu do dochodów i kosztów, tj. ich klasyfikacji i prezentacji w sprawozdaniu z dochodów, na uwagę zasługują trzy kwestie, a mianowicie:

- podstawą podziału dochodów na przychody i zyski oraz podziału kosztów na koszty i straty jest ich występowanie w zwyczajnej działalności jednostki; przychody i koszty muszą w niej występować w sposób ciągły lub regularnie z większą lub mniejszą częstotliwością; zyski i straty mogą występować i nie dzieje się to regularnie,

- oddzielne przedstawianie zysków i strat nie jest nakazem, lecz zwyczajem dobrą praktyką stosowaną ze względu na użyteczność tych informacji przy podejmowaniu decyzji gospodarczych, 
- przedstawianie zysków i strat w wartości netto, czyli po pomniejszeniu dochodów o odnośne koszty i kosztów po pomniejszeniu o odnośne dochody, uzasadnione jest tym, że dochody np. ze zbycia aktywów trwałych nie świadczą o rozmiarach podmiotu sprawozdawczego oraz o jego rozwoju, a wręcz przeciwnie, np. zbywanie aktywów trwałych może być sposobem na przetrwanie lub ratunek przed upadłością podmiotu. Nie traktuje się ich zatem jako przychodów. Miarą aktywności jednostki czy też grupy kapitałowej są przychody, czyli dochody, które powstają w zwyczajnej działalności.

Odnosząc się jeszcze do pierwszej kwestii, należy zauważyć, że założenia koncepcyjne w wersji anglojęzycznej operują określeniem „działalność zwyczajna” (ordinary activities), które w wersji polskojęzycznej zostało przetłumaczone jako „działalność operacyjna”, podczas gdy działalność operacyjna (operating activities) jest pojęciem zdefiniowanym w MSR 7 „Sprawozdanie z przepływów pieniężnych” (Międzynarodowe Standardy Sprawozdawczości Finansowej... 2016). Działalność ta jest wyróżniona z całokształtu działalności na podstawie rodzaju działalności i traktowana jako podstawowy jej rodzaj, oprócz inwestowania, czyli działalności inwestycyjnej (investing activities), i finansowania, czyli działalności finansowej (financing activities). Działalność zwyczajna (czy też działania zwyczajne, czyli prowadzone zwykle) jest wyróżniona z całokształtu działalności jednostki na innej podstawie podziału, a mianowicie na podstawie regularności transakcji i innych zdarzeń. Transakcje i inne zdarzenia występujące sporadycznie, nieregularnie są treścią działalności, która zwykle nie jest prowadzona. W sprawozdaniu z dochodów przedstawia się dochody (przychody) i koszty oraz wynik osiągnięty na zwyczajnej działalności, a następnie dochody (zyski) i straty z transakcji i innych zdarzeń, doprowadzające wynik osiągnięty na zwyczajnej działalności do wyniku przed opodatkowaniem.

\section{Dochody i koszty finansowe według Założeń koncepcyjnych sprawozdawczości finansowej i w polskiej wersji dokumentu oraz według ustawy o rachunkowości}

W założeniach koncepcyjnych zwraca się uwagę na możliwość stosowania różnych sposobów prezentacji dochodów i kosztów w sprawozdaniu z dochodów, zależnie od użyteczności informacji dla osób podejmujących decyzje na podstawie sprawozdania finansowego. Powszechną praktyką jest rozróżnianie tych składników dochodów i kosztów, które powstały w zwyczajnej działalności (ordinary activities) oraz tych, które powstały poza tą działalnością. W polskojęzycznej wersji założeń koncepcyjnych, określenie ordinary activities zostało przetłumaczone jako „podstawowa działalność operacyjna”, co sugeruje automatyczne 
wykluczenie z dochodów i kosztów tej działalności pozycji związanych z innymi rodzajami działalności, tj. działalnością inwestycyjną (inwestowaniem) i finansową (finansowaniem) czy też dochodów i kosztów będących dochodami i kosztami działalności operacyjnej, ale mających charakter finansowy, które powstają w zwyczajnej działalności jednostki, np. różnice kursowe związane z należnościami i zobowiązaniami z tytułu dostaw i usług.

Celem rozróżnienia tych składników dochodów i kosztów, które powstały w zwyczajnej działalności, oraz tych, które powstały poza tą działalnością, jest użyteczność źródła pochodzenia danej pozycji dochodów lub kosztów w ocenie zdolności jednostki do generowania w przyszłości środków pieniężnych i ich ekwiwalentów. Nie jest prawdopodobne, aby działania incydentalne, np. sprzedaż inwestycji długoterminowej, powtarzały się w regularnych odstępach czasu.

Rodzaje działalności jednostki są zdefiniowane w MSR 7 „Sprawozdanie z przepływów pieniężnych". Według anglojęzycznej wersji standardu (IAS 7 Statement of Financial Position): „Operating activities are the principal revenue-producing activities of the entity and other activities that are not investing or financing activities. Investing activities are the acquisition and disposal of long-term assets and other investments not included in cash equivalents. Financing activities are activities that result in changes in the size and composition of the contributed equity and borrowings of the entity" (IFRS... 2016, s. A841).

W polskojęzycznej wersji MSR 7 „Sprawozdanie z przepływów pieniężnych” czytamy: „Działalność operacyjna jest podstawowym rodzajem działalności powodującej powstawanie przychodów oraz każdym innym rodzajem działalności, która nie ma charakteru działalności inwestycyjnej i finansowej. Działalność inwestycyjna jest działalnością polegającą na nabywaniu i sprzedaży aktywów długoterminowych oraz innych inwestycji długoterminowych niezaliczanych do ekwiwalentów środków pieniężnych. Działalność finansowa jest działalnością, w wyniku której zmianie ulega wysokość i struktura wniesionego kapitału własnego oraz zadłużenia jednostki" (Międzynarodowe Standardy Sprawozdawczości Finansowej... 2016, s. 899).

Przetłumaczone na język polski definicje rodzajów działalności zawierają kilka nieścisłości, a mianowicie:

- w polskojęzycznej wersji definicji wyróżnionych trzech rodzajów działalności słowo „działalność” wyrażono w liczbie pojedynczej, podczas gdy w anglojęzycznej wersji wyrażono je - nie bez powodu - w liczbie mnogiej;

- konsekwencją powyższej rozbieżności jest dwukrotne wprowadzenie do polskojęzycznej definicji działalności operacyjnej słowa „rodzaj”, co spowodowało „rozmnożenie” rodzajów działalności i wyróżnienie oprócz działalności operacyjnej, inwestycyjnej i finansowej innych rodzajów działalności, która nie ma charakteru działalności inwestycyjnej i finansowej; w anglojęzycznej wersji 
standardu istotą działalności operacyjnych są podstawowe działalności powodujące powstawanie przychodów jednostki oraz inne działalności, które nie są inwestycyjnymi i finansowymi; nie ma tu mowy o podstawowym rodzaju i innych rodzajach działalności;

- w polskojęzycznej wersji definicji działalności inwestycyjnych jest mowa o nabywaniu i sprzedaży aktywów długoterminowych oraz innych inwestycji długoterminowych niezaliczanych do ekwiwalentów środków pieniężnych, podczas gdy w anglojęzycznej wersji jest mowa o nabywaniu i zbywaniu aktywów długoterminowych oraz innych inwestycji niezaliczanych do ekwiwalentów środków pieniężnych; polskojęzyczna wersja definicji zawiera istotną nieścisłość i poważny błąd. Nieścisłość zawarta w tej definicji dotyczy błędnego użycia słowa „sprzedaż” - przeciwieństwem nabywania jest zbywanie, a sprzedaż jest tylko jedną z form zbytu; błąd polega na sprowadzeniu działalności inwestycyjnej do „nabywania i sprzedaży aktywów długoterminowych oraz innych inwestycji długoterminowych", z czego wynika, że działalność inwestycyjna nie obejmuje inwestycji, które nie są długoterminowymi, oraz że działalność inwestycyjna obejmuje aktywa długoterminowe oraz inne inwestycje długoterminowe, a więc coś innego niż aktywa; stąd pojawia się pytanie, w co oprócz aktywów można inwestować;

- określenie trzeciego rodzaju działalności w anglojęzycznej wersji definicji słowem „financing”, a nie słowem „finance” oznacza działalność polegającą na finansowaniu, a nie finansową, jak ją określono w wersji polskojęzycznej; pozornie niewielka różnica w nazwie powoduje znaczną trudność w zrozumieniu tej działalności, a w konsekwencji częste utożsamianie jej z wszelkimi operacjami finansowymi bez względu na to, jakiej działalności dotyczą (np. różnice kursowe powstałe na rozrachunkach z tytułu dostaw i usług, a więc na działalności operacyjnej).

\section{Przychody i koszty finansowe według ustawy o rachunkowości}

Ustawowe pojęcia przychodów i zysków oraz kosztów i strat, jak również ich definicje odpowiadają odpowiednio przedstawionym wyżej na podstawie założeń koncepcyjnych pojęciom dochodów oraz kosztów.

Zgodnie z ustawą o rachunkowości przychody i koszty finansowe nie są ujmowane w kosztach i przychodach działalności operacyjnej. $Z$ tego powodu najczęściej są kojarzone z działalnością finansową podmiotu sprawozdawczego.

Definicje poszczególnych rodzajów działalności zawarte w polskojęzycznej wersji MSR 7 stały się podstawą definicji tych pojęć w ustawie o rachunkowości. Ustawowe definicje rodzajów działalności zawierają - w porównaniu z definicjami zamieszczonymi w MSR 7 - sformułowania pozbawione istotnych nieścisłości, 
a ponadto w definicjach działalności inwestycyjnej i finansowej zawierają ważne uszczegółowienie zakresu zdarzeń wchodzących w zakres tych rodzajów działalności, jakimi są pieniężne koszty i korzyści.

Definicje rodzajów działalności służą do właściwego określenia wartości przepływów pieniężnych w sprawozdaniu z przepływów pieniężnych (według MSSF), a według ustawy o rachunkowości w rachunku przepływów pieniężnych. Wzajemna zależność pomiędzy poszczególnymi częściami sprawozdania finansowego sprawia, że definicje te powinny być traktowane jako wiążące przy rozpatrywaniu problemów związanych z informacjami prezentowanymi w innych częśsiach sprawozdania finansowego, w tym według MSSF w sprawozdaniu z wyniku i pozostałych całkowitych dochodów, zaś według ustawy o rachunkowości w rachunku zysków i strat. Tendencja ta jest zauważalna w sprawozdaniu finansowym sporządzanym według MSSF. W sprawozdaniu finansowym sporządzanym według ustawy o rachunkowości wymaga się prezentacji przychodów i kosztów finansowych bez względu na rodzaj działalności, z którą są związane. W ustawowych wzorach rachunku zysków i strat (w wariancie kalkulacyjnym i porównawczym) przychody i koszty finansowe z dalszym ich uszczegółowieniem prezentowane są odrębnie.

Ściśle określona odrębna prezentacja przychodów i kosztów finansowych w rachunku zysków i strat stała się jedną z przyczyn przypisywania tych kategorii ekonomicznych w polskiej literaturze przedmiotu do działalności finansowej bez względu na jej definicję, a w konsekwencji do ustalania wyniku na tej działalności, analogicznie jak w przypadku wyniku na pozostałej działalności operacyjnej.

Inną przyczyną opisanego nieporozumienia jest uproszczone nazewnictwo w języku polskim, na co wskazano wyżej, omawiając definicję działalności finansowej. Działalność finansowa kojarzy się w najprostszym rozumieniu tego słowa z przychodami i kosztami finansowymi, bez głębszych dociekań, co ten przymiotnik określa w odniesieniu do działalności, a co w odniesieniu do przychodów i kosztów. W odniesieniu do działalności określa jej rodzaj, a w odniesieniu do przychodów i kosztów określa ich charakter, a nie związek z działalnością finansową. Przychody i koszty finansowe mogą być związane z każdym z trzech rodzajów działalności - przykładem są wskazywane wcześniej różnice kursowe.

Kolejną przyczyną nieporozumienia polegającego na przypisywaniu kosztów i przychodów finansowych do działalności finansowej bez względu na jej definicję jest nadinterpretacja określenia zawartego w art. 42 ustawy o rachunkowości. W ustępie 1 tego artykułu uregulowano zakres elementów cząstkowych składających się na wynik finansowy netto w jednostkach innych niż banki, zakłady ubezpieczeń i zakłady reasekuracji. Elementami cząstkowymi wyniku finansowego netto w tych jednostkach są: 
- wynik działalności operacyjnej, w tym z tytułu pozostałych przychodów i kosztów operacyjnych,

- wynik operacji finansowych,

- obowiązkowe obciążenia wyniku finansowego z tytułu podatku dochodowego, którego podatnikiem jest jednostka, i płatności z nim zrównanych, na podstawie odrębnych przepisów.

Zdefiniowano również pojęcia wyniku działalności operacyjnej i wyniku operacji finansowych.

„Wynik działalności operacyjnej stanowi różnicę między przychodami netto ze sprzedaży produktów, towarów i materiałów, z uwzględnieniem dotacji, opustów, rabatów i innych zwiększeń lub zmniejszeń, bez podatku od towarów i usług oraz innych podatków bezpośrednio związanych z obrotem, oraz pozostałymi przychodami operacyjnymi a wartością sprzedanych produktów, towarów i materiałów wycenionych w kosztach wytworzenia albo cenach nabycia, albo zakupu, powiększoną o całość poniesionych od początku roku obrotowego kosztów ogólnych zarządu, sprzedaży produktów, towarów i materiałów oraz pozostałych kosztów operacyjnych" (Ustawa z dnia 29 września 1994 r. ..., art. 42, ust. 2).

W przytoczonej definicji wyniku działalności operacyjnej nie ma mowy o wyniku pozostałej działalności operacyjnej.

Wynik operacji finansowych stanowi różnicę między przychodami finansowymi, w szczególności z tytułu dywidend (udziałów w zyskach), odsetek, zysków ze zbycia oraz aktualizacji wartości inwestycji innych niż wymienione w art. 28, ust. 1, pkt 1a (chodzi tu o inwestycje niefinansowe, czyli nieruchomości oraz wartości niematerialne i prawne), nadwyżki dodatnich różnic kursowych nad ujemnymi a kosztami finansowymi, w szczególności z tytułu odsetek, strat ze zbycia oraz aktualizacji wartości inwestycji innych niż wymienione w art. 28, ust. 1, pkt 1a (chodzi tu o inwestycje niefinansowe, czyli nieruchomości oraz wartości niematerialne i prawne), nadwyżki ujemnych różnic kursowych nad dodatnimi, z wyjątkiem odsetek, prowizji, dodatnich i ujemnych różnic kursowych, o których mowa w art. 28, ust. 4 (chodzi tu o możliwe, uzasadnione niezbędnym, długotrwałym przygotowaniem towaru lub produktu do sprzedaży bądź długim okresem wytwarzania produktu zwiększenie ceny nabycia lub kosztu wytworzenia o koszty obsługi zobowiązań zaciągniętych w celu finansowania zapasu towarów lub produktów w okresie ich przygotowania do sprzedaży bądź wytworzenia i związane z nimi różnice kursowe, pomniejszone o przychody z tego tytułu) i ust. 8, pkt 2 (chodzi tu o aktywowanie w cenie nabycia i koszcie wytworzenia środków trwałych w budowie, środków trwałych oraz wartości niematerialnych i prawnych kosztów obsługi zobowiązań zaciągniętych w celu ich finansowania i związanych z nimi różnic kursowych, pomniejszonych o przychody z tego tytułu poniesionych przez jednostkę za okres budowy, montażu, przystosowania i ulep- 
szenia, do dnia bilansowego lub przyjęcia do używania) (Ustawa z dnia 29 września 1994 r...., art. 42, ust. 3).

Użyte w ustawie określenie ,wynik operacji finansowych” wskazuje jednoznacznie na charakter operacji, a nie na rodzaj działalności. Innymi słowy, operacje finansowe to nie to samo co działalność finansowa.

\section{Skutki liczbowe różnego podejścia do kosztów i przychodów finansowych}

W rezultacie różnego rozumienia i klasyfikowania działalności podmiotu sprawozdawczego oraz ujmowania i prezentacji kosztów i przychodów finansowych ich wartości wyrażające pieniężne rezultaty tych samych transakcji i innych zdarzeń mogą kształtować się odmiennie.

W sprawozdaniach sporządzonych według MSSF wartości kosztów i przychodów finansowych różnią się w zależności od wariantu sprawozdania z wyniku. Inne kwoty będą ujawnione w wariancie porównawczym, inne w wariancie kalkulacyjnym. Zwykle będą to kwoty kosztów finansowych (finance cost) po pomniejszeniu o ewentualne dochody finansowe (finance income). Podobne zróżnicowanie wystąpi w pozycji ,pozostałe koszty”, co ilustruje przykład zaprezentowany w tabelach 1 i 2.

Tabela 1. Sprawozdanie z wyniku (część sprawozdania z wyniku i pozostałych całkowitych dochodów) za rok kończący się 31 grudnia 20X7 - wariant kalkulacyjny

\begin{tabular}{|l|c|c|}
\hline \multicolumn{1}{|c|}{ Wyszczególnienie } & $20 X 7$ & $20 X 6$ \\
\hline Przychody & 390000 & 355000 \\
\hline Koszt własny sprzedaży & $(245000)$ & $(230000)$ \\
\hline Zysk brutto & 145000 & 125000 \\
\hline Pozostałe dochody & 20667 & 11300 \\
\hline Koszty sprzedaży & $(9000)$ & $(8700)$ \\
\hline Koszty administracyjne & $(20000)$ & $(21000)$ \\
\hline Pozostałe koszty & $(2100)$ & $(1200)$ \\
\hline Koszty finansowe & $(8000)$ & $(7500)$ \\
\hline Udział w zysku jednostek stowarzyszonych & 35100 & 30100 \\
\hline Zysk przed opodatkowaniem & 161667 & 128000 \\
\hline Podatek dochodowy & $(40417)$ & $(32000)$ \\
\hline Zysk za rok z działalności kontynuowanej & 121250 & 96000 \\
\hline Strata za rok z działalności zaniechanej & - & $(30500)$ \\
\hline Zysk za rok & 121250 & 65500 \\
\hline
\end{tabular}

Źródło: opracowanie własne na podstawie (A Guide through IFRS... 2013, s. B1111-B1114). 
Tabela 2. Sprawozdanie z wyniku (część sprawozdania z wyniku i pozostałych całkowitych dochodów) za rok kończący się 31 grudnia 20X7 - wariant porównawczy

\begin{tabular}{|l|c|c|}
\hline \multicolumn{1}{|c|}{ Wyszczególnienie } & $20 X 7$ & $20 X 6$ \\
\hline Przychody & 390000 & 355000 \\
\hline Pozostałe dochody & 20667 & 11300 \\
\hline Zmian stanu zapasów wyrobów gotowych i produkcji w toku & $(115100)$ & $(107900)$ \\
\hline Koszt wytworzenia świadczeń na własne potrzeby & 16000 & 15000 \\
\hline Zużycie surowców i materiałów & $(96000)$ & $(92000)$ \\
\hline Świadczenia pracownicze & $(45000)$ & $(43000)$ \\
\hline Amortyzacja & $(19000)$ & $(17000)$ \\
\hline Utrata wartości rzeczowych aktywów trwałych & $(4000)$ & - \\
\hline Pozostałe koszty & $(6000)$ & $(5500)$ \\
\hline Koszty finansowe & $(15000)$ & $(18000)$ \\
\hline Udział w zysku jednostek stowarzyszonych & 35100 & 30100 \\
\hline Zysk przed opodatkowaniem & 161667 & 128000 \\
\hline Podatek dochodowy & $(40417)$ & $(32000)$ \\
\hline Zysk za rok z działalności kontynuowanej & 121250 & 96000 \\
\hline Strata za rok z działalności zaniechanej & - & $(30500)$ \\
\hline Zysk za rok & 121250 & 65500 \\
\hline
\end{tabular}

Źródło: opracowanie własne na podstawie (A Guide through IFRS... 2013, s. B1111-B1114).

W wariancie kalkulacyjnym sprawozdania z wyniku ujawnione są niższe kwoty w pozycji „koszty finansowe” niż w wariancie porównawczym. Podobnie w pozycji „,pozostałe koszty”. W wariancie kalkulacyjnym koszty finansowe w wysokości 7000 zostały przypisane do poszczególnych funkcji i są ujęte odpowiednio w pozycjach: „,koszt własny sprzedaży”, „koszty sprzedaży”, „,koszty administracyjne”, a także „pozostałe koszty”. Podobnie różnica pozostałych kosztów w kwocie 3900 została ukształtowana pod wpływem przypisania tych kosztów do funkcji, z którymi są związane. W pozycjach „koszty finansowe” i „pozostałe koszty” ujawnia się kwoty kosztów finansowych oraz pozostałych kosztów, których nie można przypisać do poszczególnych funkcji.

W sprawozdaniach finansowych sporządzonych według ustawy o rachunkowości koszty i przychody finansowe (a także pozostałe koszty i przychody operacyjne) ujawniane są w takich samych kwotach zarówno w wariancie porównawczym, jak i kalkulacyjnym. 


\section{Wnioski}

Z przedstawionych rozważań dotyczących przychodów i kosztów finansowych prezentowanych w sprawozdaniu finansowym wynika, że kwoty przychodów i kosztów finansowych są zróżnicowane w zależności od:

- podstawy sporządzenia sprawozdania finansowego (sprawozdanie sporządzone według MSSF i według ustawy o rachunkowości),

- wariantu sprawozdania z wyniku w sprawozdaniu z wyniku i pozostałych całkowitych dochodów (prezentacja kosztów według funkcji, prezentacja kosztów według rodzaju, innymi słowy, odpowiednio: wariant kalkulacyjny i wariant porównawczy) w sprawozdaniu finansowym sporządzonym według MSSF.

Przyczyną zróżnicowania kwot przychodów i kosztów finansowych w sprawozdaniach sporządzonych według MSSF i ustawy o rachunkowości jest różne podejście do klasyfikacji działalności jednostki i związanych z nią dochodów i kosztów.

W MSSF w działalności jednostki wyróżnia się działalność zwyczajną i taką, która występuje rzadko, nieregularnie, a więc jest działalnością niezwyczajną. Do tak wyróżnionych działalności przypisuje się dochody (przychody i zyski) oraz koszty (koszty i straty). Dochody i koszty finansowe związane z działalnością zwyczajną ujmowane są w kosztach tej działalności. Ujmowanie to jest zależne od sposobu prezentacji kosztów (według funkcji - wariant kalkulacyjny, według rodzaju - wariant porównawczy).

W wariancie kalkulacyjnym dochody i koszty finansowe związane z działalnością zwyczajną ujmowane są per saldo odpowiednio w kosztach dóbr sprzedanych, w kosztach sprzedaży, w kosztach administracyjnych (zarządu) oraz w pozostałych kosztach. Dochody i koszty finansowe niezwiązane z działalnością zwyczajną są ujmowane i prezentowane odrębnie.

W wariancie porównawczym (prezentacja kosztów według rodzaju) dochody i koszty finansowe są ujmowane i prezentowane per saldo odrębnie, i obejmują zarówno pozycje związane, jak i niezwiązane z działalnością zwyczajną jednostki. Ujmowanie i prezentacja kosztów według rodzaju uniemożliwia ich kształtowanie pod wpływem kategorii finansowych.

Ustawa o rachunkowości, definiując pozostałe koszty i przychody operacyjne z wykluczeniem z ich zakresu kategorii finansowych oraz określając wynik na operacjach finansowych, stworzyła podstawy do wyróżnienia w rachunku zysków i strat przychodów i kosztów tzw. podstawowej działalności operacyjnej i pozostałej działalności operacyjnej, a także przychodów i kosztów finansowych, czyli powstałych na operacjach finansowych bez względu na to, z jaką działalnością operacje finansowe były związane. Ustawa określiła również 
wymagania w zakresie prezentacji przychodów (przychodów i zysków) oraz kosztów (kosztów i strat). W rezultacie tych regulacji przychody i koszty finansowe prezentowane są odrębnie. Ustawa o rachunkowości traktuje zatem operacje finansowe w sposób szczególny i wymaga odrębnego ujmowania i prezentacji przychodów i kosztów finansowych bez względu na ich związek z poszczególnymi rodzajami działalności oraz określa wynik na operacjach finansowych jako element wyniku finansowego. Warto dodać, że analogiczne zróżnicowania rozwiązań dotyczą prezentowanych kwot pozostałych przychodów i pozostałych kosztów operacyjnych.

Informacje o ważnych kategoriach ekonomicznych, jakimi są przychody i koszty finansowe prezentowane w sprawozdaniach finansowych sporządzonych według różnych zasad, nie mogą być aktualnie przedmiotem badań porównawczych bez wykonania skomplikowanych zabiegów w celu doprowadzenia ich do porównywalności. Wzmożenie prac nad definicjami i klasyfikacjami omawianych kategorii ekonomicznych pozwoliłoby wyeliminować istniejące różnice rozwiązań i wynikające z nich trudności w tym zakresie.

Innego rodzaju problemem badawczym jest znalezienie odpowiedzi na pytanie, czy i w jakim zakresie rozwiązania polskiej ustawy o rachunkowości i polska praktyka rachunkowości wpływają na informacje przedstawiane w sprawozdaniach finansowych sporządzanych według MSSF.

\section{Literatura}

The Conceptual Framework for Financial Reporting (2016), (w:) IFRS 2016, IFRS Foundation, London.

A Guide through International Financial Reporting Standards. Part B (2013), IFRS Foundation, London.

IFRS 2016 (2016), IFRS Foundation, London.

Międzynarodowe Standardy Sprawozdawczości Finansowej 2016 (2016), SKwP, IFRS Foundation, Warszawa.

Rozporządzenie Komisji (WE) nr 1126/2008 z dnia 3 listopada 2008 r. przyjmujące określone międzynarodowe standardy rachunkowości zgodnie z rozporządzeniem (WE) nr 1606/2002 Parlamentu Europejskiego i Rady, 02008R1126-PL-01.01.2016-015.003-3.

Ustawa z dnia 29 września 1994 r. o rachunkowości, Dz.U. 2016, poz. 1047, ze zm.

Założenia koncepcyjne sporzqdzania i prezentacji sprawozdań finansowych (2001), (w:) Międzynarodowe Standardy Rachunkowości 2001, IASB, SKwP, Warszawa.

Założenia koncepcyjne sprawozdawczości finansowej (2016), (w:) Międzynarodowe Standardy Sprawozdawczości Finansowej 2016, SKwP, IFRS Foundation, Warszawa. 


\section{Defining and Classifying Economic Categories in Scientific Research on Contemporary Financial Phenomena}

(Abstract)

Scientific research on contemporary financial phenomena requires the use of information about economic categories, a significant part of which is disclosed in financial statements. High quality research is contingent upon the cohesion of the definitions used and the classification of economic categories.

The main purpose of this paper is to draw the attention of theoreticians of finance, law and accounting to the need to intensify research geared to improving or creating a new definition and classification of the economic categories disclosed in the financial statements of accounting entities.

To justify this thesis, the paper offers an analysis of the current state of financial statements drawn up according to IFRS and the Polish accounting law. It focuses on information about income and costs as well as the use of the term "financial activity" at the normative, educational and economic level. The reasons for misunderstandings in this field are discussed, as are the results of those misunderstandings. This may help in the production of research aimed preventing both, and thus at improving the creation of crucial information for the development of theory of law and economic practice.

Keywords: economic category, financial income, financial cost, financial activity. 